\title{
Physical-Chemical Evaluation of Wines Subjected to Gamma Irradiation for Aging
}

\author{
Marcia N. C. Harder ${ }^{1,2}$, Lucia A. C. S. Silva ${ }^{1}$, Juliana A. Pires ${ }^{2}$, Mariana Scanholato ${ }^{2}$, Valter Arthur, \\ ${ }^{1}$ Center of Nuclear Energy in Agriculture (CENA/USP - SP), Department of Radiobiology and Environment, Av. Centenário, 303, \\ 13400-960, Piracicaba, SP, Brazil \\ ${ }^{2}$ Technology College of Piracicaba (Fatec Piracicaba/CEETEPS - SP), Agroindustry Department and Biofuel, Av. Diácono Jair de \\ Oliveira, 651, 13414-155, Piracicaba, SP, Brazil \\ *Corresponding Author: arthur@cena.usp.br
}

Copyright (C) 2013 Horizon Research Publishing All rights reserved.

\begin{abstract}
The wine is a beverage made from the fermentation of sugars contained in grapes or grape juice, using yeast. Wines can be classified according to the amount of sugar they contain: dry, soft or sweet. Depending on the need for aging, they may be classified as young or aged. Modern methods of aging use gamma irradiation. There are several reasons for these types of procedure in wines, among them are: sterilization of the wort, changes in sensory characteristics of the wine, and accelerated aging. In this study, samples of soft red wine were obtained in the city of São Pedro in the local market, all bottles being of the same batch. The samples and the control were directly irradiated with gamma irradiation in polyethylene bags with doses of $1 \mathrm{KGy}$ and $3 \mathrm{KGy}$, at a rate of $0.396 \mathrm{kGy} / \mathrm{h}$. The evaluation parameters were tartaric acid, brix, $\mathrm{pH}$, alcohol content and color. For statistical purposes, the Tukey test at 5\% significance level was used. From the results obtained, it may be concluded that by the physicochemical analysis for soft red wines the best dose was $6 \mathrm{kGy}$ and the color and the $\mathrm{pH}$ are presented as possible indicators of aging.
\end{abstract}

Keywords Beverage, Ionizing Radiation, Accelerated Red Wine Aging

\section{Introduction}

The wine is alcohol drink made from the fermentation of sugar contained in grapes or grapes juice and is intertwined with the history of mankind since its inception. Only it acquired a sacramental significance and endowed with healing powers and actually has its own life. For a long time, throughout its history and the history of mankind, was the only source of comfort and courage, the only medicine and antiseptic, the only way that man had courage to recover and overcome the fatigue and sadness. Certain properties of wine were much more important for our ancestors than to us. During two thousand years of medical and surgical history, wine was the universal antiseptic and the only. With it was washed the wounds. For doctors the wine was indispensable to the late nineteenth century. In the words of the Talmud "lacking wine, there is need for drugs." A medical text (VI $\mathrm{BC}$ ), developed in India, defines the wine as the "tonic of mind and body, the antidote for insomnia, sadness and fatigue (...) furthermore can stimulate the appetite, happiness and digestion". Today the empirical knowledge uses very similar terms to characterize the wine specific therapeutic virtues, especially in relation to heart disease [1].

According to the same author, the solid components that give color to red wines and the extract found in the skins of red grapes, have a substance called resveratrol. Among the various components of resveratrol, we also highlight the flavonoids, which are important elements also present in wines, responsible for many health benefits, especially in red wines.

Wines can be classified according to the amount of sugar, which are: dry, smooth or sweet. However there is another category, this is characterized by the need or not an aging process. Being divided into a young wine and aged wine.

The method used for aging is performed under oxygen, keeping the beverage with caution to limit the maximum dissolved oxygen [2]. It can be stored in bottles or in wooden casks.

The most modern method of aging however is the use of irradiation. There are several reasons for this type of procedure in wines, among them are: sterilization of wine; changes in sensory characteristics of wine and accelerated aging $[3,4]$.

For food radiation is used an isotope Cobalt-60 as a source of gamma radiation, due to its availability; cost and present in solid metallic form; is also insoluble in water, which ensures greater safety. It is obtained by pumping the metal with neutrons in a Cobalt-59 nuclear reactor [5, 6]. Moreover the food does not have direct contact with the nuclear source is virtually impossible that the nuclear contamination occurs.

According to Han (2007) [7] ionizing radiation is a nonthermal process utilized to achieve the preservation of 
food. At a maximum commercial irradiation dose of 10kGy, irradiation does not impart heat to the food and the nutritional quality of the food is generally unaffected. The irradiation process can reduce microbial contamination on food, resulting in improved microbial safety as well as extended shelf life of the food. In the last decade, many studies have been conducted on irradiation of various foods, especially foods susceptible to foodborne outbreaks, such as meat and meat products. Nonetheless, from a commercial standpoint, foods are generally prepackaged in the final form (aka case ready) before irradiation to avoid recontamination.

Despite the vast amount of research on food irradiation, little is known about the radiation on fermented beverages like wine. Aging through this method has a factor in favor of winemakers, the reduced time of the process. Therefore it is extremely important to establish whether there are changes in the aroma compounds with the acceleration of the aging process by irradiation.

Premature aging can be a desirable feature, occurring in an experiment of application of gamma irradiation in wines made from grapes. They can also be evaluated aromatic and visual changes, increased tannin, changes in $\mathrm{pH}$ and alcohol levels, indicating premature aging of this beverage. By the above this study aims to evaluate the effects of gamma irradiation on wines, including the possibility of premature aging.

\section{Materials and Methods}

\subsection{Material}

Samples of soft red wine were obtained in local market of Sao Pedro City, Sao Paulo, Brazil. All bottles are being of the same batch and the brand "Chapinha".

\subsection{Treatments}

We carried out the separation of soft red wine samples in containers of PET, dividing in packs of $300 \mathrm{ml}$. After this procedure, they were closed, with four separate bottles for the control and the remaining irradiated at doses of $1 \mathrm{kGy}$, and $3 \mathrm{kGy} 6 \mathrm{kGy}$ in a rate of dose of $0.396 \mathrm{kGy} / \mathrm{h}$.

For the samples treatment was conducted in 220 Gammacell Excel, MDS Nordion by Cobalt 60 source to irradiate, located at the Center for Nuclear Energy in Agriculture (CENA / USP).

All protective measures for the use of nuclear energy use in food were taken in order to maintain safety standards.

\subsection{Methods}

\subsubsection{Physiochemical Analysis}

\subsubsection{Alcoholic Strength}

Samples of soft red wine were placed in the ebulliometer which was used for the alcohol content by matching the temperature in the conversion rule [8].

\subsubsection{PH}

It was certain through $\mathrm{pHmeter} \mathrm{MB}-10$, according to the recommendations of AOAC [9].

\subsubsection{Title Acidity}

It was necessary use potentiometric titled and made calculations as the volume in $\mathrm{mL}$ of $\mathrm{NaOH}$ requested to title $100 \mathrm{~mL}$ of wine to the $\mathrm{pH} 8.2$, expressed in tartaric acid percentage, having been the wine diluted in the proportion $1: 10$, according to AOAC [9].

\subsubsection{Tenor of Soluble Solids}

Measured in refratometer RT-30ATC and expressed in degrees Brix, in agreement with methodology described by AOAC [9].

\subsubsection{Color}

The colorimeter Minolta CR-200 b was used, previously calibrated in White according to pre-determined standards.

Three values of chroma were evaluated: $a^{*}, b^{*}$ and $L$. The value $a^{*}$ characterizes the color from the red $\left(+a^{*}\right)$ to the green $\left(-a^{*}\right)$; the value $b^{*}$ indicates the color from the yellow $\left(+b^{*}\right)$ to the blue $\left(-b^{*}\right)$. The value $\mathrm{L}$ determine the light ranging from white $(\mathrm{L}=100)$ to black $(\mathrm{L}=0)$. The chroma is the ratio between $\mathrm{a}^{*}$ and $\mathrm{b}^{*}$, where the real color can be obtained. Hue-Angle is the angle between $a^{*}$ and $b^{*}$, indicating the color saturation of the analyzed object.

To estimate chroma value, the following formula was adopted (1) and to estimate the Hue-Angle, formula (2) [10].

$$
\begin{aligned}
& \mathrm{C}=\sqrt{ }(\mathrm{a} 2+\mathrm{b} 2) \\
& \mathrm{H}^{\mathrm{o}}=\operatorname{arcpg} \mathrm{b}^{*} / \mathrm{a}^{*}
\end{aligned}
$$

\subsection{Statistical Analysis}

The employed experimental delineate was entirely at random, with three repetitions for treatment. The obtained results were submitted to the variance analysis by the test $\mathrm{F}$, and the comparison of the averages obtained in the different treatments analyzed second test of Tukey $(p<0.05)$, with use of the SAS program [11].

Table 1. Means obtained in soft red wine alcohol strenght, $\mathrm{pH}$, title acidity and soluble solids with increasing gamma radiation doses

\begin{tabular}{|c|c|c|c|c|}
\hline Sample & Alcoholic strength (\%) & $\mathrm{pH}$ & Title acidity Tartaric acid (\%) & Tenor of soluble solids ( ${ }^{\circ}$ Brix) \\
\hline Control & $11.80 \pm 0.001 \mathrm{a} 2$ & $3.81 \pm 0.01 \mathrm{a}$ & $0.66 \pm 0.01 \mathrm{~b}$ & $16.17 \pm 0.00 \mathrm{~b}$ \\
\hline $1 \mathrm{kGy}$ & $11.70 \pm 0.10 \mathrm{a}$ & $3.63 \pm 0.02 \mathrm{~b}$ & $0.63 \pm 0.01 \mathrm{~b}$ & $16.31 \pm 0.04 \mathrm{a}$ \\
\hline $3 \mathrm{kGy}$ & $11.80 \pm 0.20 \mathrm{a}$ & $3.66 \pm 0.04 \mathrm{~b}$ & $0.57 \pm 0.02 \mathrm{c}$ & $16.07 \pm 0.00 \mathrm{c}$ \\
\hline $6 \mathrm{kGy}$ & $11.70 \pm 0.11 \mathrm{a}$ & $3.49 \pm 0.02 \mathrm{c}$ & $1.38 \pm 0.01 \mathrm{a}$ & $16.20 \pm 0.04 \mathrm{~b}$ \\
\hline
\end{tabular}

${ }^{1}$ Media \pm Standard Deviation;

$;^{2}$ medias with different word(s) in the vertical they differ significantly at the level of $5 \%$. 


\section{Results and Discussion}

\subsection{Physiochemical Analysis}

Table 1 shows the results means obtained by the statistics of alcohol strength, $\mathrm{pH}$, title acidity and tenor of soluble solids in the samples of soft red wine.

\subsubsection{Alcoholic strength}

For what is showing on Table 1 it is possible to observe that the doses used in the samples of soft red wines, alcohol content is not altered by the absence of statistically significant difference.

These results are according to Miranda (2006) [12], which used Co60 gamma irradiation in sugar cane spirits that the alcohol strength showed a gradual decrease as increasing doses. But Souza (2000) [13] obtained different results using gamma radiation in sugar cane spirit with for aging

The gamma radiation process differs from normal aging, occurring in wooden barrels. For this the reduction of alcohol strength is given by the absorption of the wood due to the porosity and then evaporation to the environment. Perhaps the distinction about the results was by the different way of storage.

According to Brazilian legislation, the results are according as the art. 9 of Law No. 7678 of 8 November 1988 that says that table wine must have between $8.6 \%$ to $14 \%$ alcohol [14].

\subsection{2. $\mathrm{PH}$}

Evaluating even the same table for the results of $\mathrm{pH}$, it is observed that there were apparent decreases with increasing dose. The control showed the highest value. Between doses of 1 and $3 \mathrm{kGy}$ there was no significant change. However the $6 \mathrm{kGy}$ sample was presented the lowest value statistically. Souza (2000) [13] shows that $\mathrm{pH}$ reduction by radiation in sugar cane spirit as a factor in aging. Therefore, it is demonstrated that there was probable aging.

\subsubsection{Title Acidity}

According to Karasz et al. (2005) [15] their work presents the increase in acidity values as aging. According to Table 1 are showed significant changes. The values established between the control and $1 \mathrm{kGy}$ dose showed no statistical variation. With increasing dose there was a relative drop at $3 \mathrm{kGy}$. But with the increase to $6 \mathrm{kGy}$ there was an increase in value achieved with statistical significance. So, this is evaluated as a possible characteristic of aging.

\subsubsection{Tenor of Soluble Solids}

According with showed on Table1 the dose of irradiation at $1 \mathrm{kGy}$ is statistically significantly increases the soluble solids in the samples, while $3 \mathrm{kGy}$ doses have the opposite effect, ie, statistically significantly lower. Already 6kGy doses have no effect of decreased or increased, as there is no difference when compared with non-irradiated samples.

During the transfer of the beverage packaging for polyethylene, a significant amount of sugar in a glass bottle, not soluble. Indicates that this wine passed by the correction process known as sugaring, ie, an increase of $1.8 \mathrm{~kg}$ of sugar per $\mathrm{hL}$ of wine to raise $1^{\circ} \mathrm{GL}$. This fact could explain, together with nature, according to Sasso, Bassin, Ranchi (2010) [16], more sugary soft red wine, the big difference found in the results of these samples compared with the results reported by Karasz et al. (2005) [15], where dry white wines aged of the variety Riesling Italico presented ${ }^{\circ}$ Brix of 1.24 to 5.25 .

\subsubsection{Color}

The Table 2 presents de color values by colorimeter parameters.

Every table must have a unique title placed at the top. Titles should be clear and concise, and they should not be complete sentences.

According to Table 2 for chroma values have change according to Aquarone, Borzani, Schmidell (2001) [1] that mentioned the colors of the ruby red to yellow brick with the aging wine. What about the hue-angle, there was a statistically significant increase, thus leading to increase in color saturation.

\section{Conclusion}

According to showed by evaluation of the physicochemical analysis for soft red wines the best dose was $6 \mathrm{kGy}$ and the color and the $\mathrm{pH}$ are presented as possible indicators of aging.

Table 2. Means of color parameters obtained in colorimetric analysis

\begin{tabular}{|c|c|c|c|c|c|}
\hline Sample & \multicolumn{2}{|c|}{ Color } & \multirow{2}{*}{ Croma } & \multirow{2}{*}{ Hue-Angle } \\
\hline & $\mathrm{L}$ & $\mathrm{A}$ & $\mathrm{B}$ & \\
\hline Control & $20.71 \pm 1.231 \mathrm{ab} 2$ & $0.38 \pm 0.07 \mathrm{~b}$ & $0.52 \pm 0.16 \mathrm{~b}$ & $0.65 \pm 0.16 \mathrm{a}$ & $0.64 \pm 0.12 \mathrm{ab}$ \\
\hline $1 \mathrm{kGy}$ & $21.74 \pm 1.35 \mathrm{a}$ & $0.28 \pm 0.10 \mathrm{~b}$ & $0.45 \pm 0,07 \mathrm{~b}$ & $0.54 \pm 0.09 \mathrm{ab}$ & $0.55 \pm 0.14 \mathrm{~b}$ \\
\hline $3 \mathrm{kGy}$ & $18.06 \pm 0.65 \mathrm{bc}$ & $0.94 \pm 0.05 \mathrm{ab}$ & $0.79 \pm 0.07 \mathrm{~b}$ & $1.23 \pm 0.05 \mathrm{~b}$ & $0.87 \pm 0.05 \mathrm{a}$ \\
\hline $6 \mathrm{kGy}$ & $16.24 \pm 1.51 \mathrm{c}$ & $1.61 \pm 0.62 \mathrm{a}$ & $1.33 \pm 0.32 \mathrm{a}$ & $2.10 \pm 0.67 \mathrm{~b}$ & $0.86 \pm 0.09 \mathrm{a}$ \\
\hline
\end{tabular}

${ }^{1}$ Media \pm Standard Deviation

${ }^{2}$ medias with different word(s) in the vertical they differ significantly at the level of $5 \%$. 


\section{Acknowledgements}

We are very grateful to experts CENA/USP and FATEC Piracicaba.

\section{REFERENCES}

[1] E. Aquarone, W. Borzani, W. Schmidell, U. A. Lima, Biotecnologia Industrial: Biotecnologia na produção de alimentos. Blucher, São Paulo, Brasil (2001).

[2] M. F. C. Pinto, "Vinho e Longevidade", http://www.portaldoenvelhecimento.org.br/revista/index.php (2011).

[3] W. M. Urbain, Food Irradiation, Academic, New York, EUA (1986).

[4] M. D. C. A. Souza, Identificação, quantificação e comparação das substâncias químicas responsáveis pelos aromas da cachaça de alambique e do rum comercial tratados pelo processo de irradiação, Tese (Doutorado). IPEN, São Paulo, Brasil (2006).

[5] L. C. Neves et al., "Radiação gama na conservação pós-colheira da nectarina (Prunus pérsica var. Nucipersica) frigoconservagada" Revista Brasileira de Fruticultura, v. 24, pp.676-679 (2002).

[6] D. T. S. Leite, "Avaliação dos efeitos da radiação gama na qualidade de abacaxi (Ananas comosus (L.) Meer) cv. Smooth Cayenne minimamente processado, armazenado em diferentes temperaturas e embalagens", Tese (Doutorado). CENA/USP, Piracicaba, Brasil (2006).

[7] J. H. Han. "Packaging for Foods Treated with Ionizing Radiation."
http://www.fda.gov/Food/IngredientsPackagingLabeling/Irra diatedFoodPackaging/ucm081399.htm (2007).

[8] A. Nogueira et al., "Análise dos indicadores físico-químicos de qualidade da sidra brasileira", SEMINA: Ciências Agrárias, v. 24, pp.289-298 (2003).

[9] AOAC, Official methods of analysis of AOAC international, AOAC, Gaithersburg, USA (2005).

[10] M. N. C. Harder, S. G. Canniatti-Brazaca, V. Arthur, "Quantitative evaluation by a digital colorimeter of the color of the egg of laying hens fed with annatto (Bixa orellana)", Revista Portuguesa de Ciências Veterinárias, v. 102, pp.339-342 (2007).

[11] Statistical Analysis System Institute, Sas/Qc. Software: usage and reference, Statpoint, Inc., Herndon, USA (1996).

[12] M. B. Miranda, J. Horii, A. R. Alcarde, "Estudo do efeito da irradiação gama $(60 \mathrm{Co})$ na qualidade da cachaça e no tonel de envelhecimento", Ciência e Tecnologia de Alimentos, v. 26, pp.772-778 (2006).

[13] H. R. Souza, "Caracterização físico-química de vinhos argentinos, chilenos e brasileiros", Trabalho de conclusão de curso, Universidade Católica de Goiás, Goiânia, Brasil (2004).

[14] Brasil, "Lei no 7.678, de 08 de Novembro de 1988. Art. 9o", http://www.uvibra.com.br/legislacao_lei7678.htm (2011).

[15] P. Karasz et al., "Influência do envelhecimento na aceitação e nas características físico-químicas de vinhos brancos Riesling Itálico brasileiros”, Alimentos e Nutrição, v.26, pp.45-50 (2005).

[16] C. Sasso, J. P. Bassin, J. C. S. Ronchi, "Vinhos. NET", http:/ /www.enq.ufsc.br/labs/probio/disc_eng_bioq/trabalhos_grad 2004/vinho/pagina_final.htm (2011). 